\title{
Evaluating the Possible Association between PD-1 (Rs11568821, $R s 2227981, R s 2227982)$ and PD-L1 (Rs4143815, Rs2890658) Polymorphisms and Susceptibility to Breast Cancer in a Sample of Southeast Iranian Women
}

\author{
Shima Karami ${ }^{1}$, Hedieh Sattarifard ${ }^{1,2}$, Mohammad Kiumarsi ${ }^{2}$, Sahel Sarabandi ${ }^{1}$, \\ Mohsen Taheri ${ }^{3}$, Mohammad Hashemi ${ }^{1 *}$, Gholamreza Bahari ${ }^{1,4 *}$, Saeid \\ Ghavami ${ }^{2,5,6 *}$
}

\begin{abstract}
Introduction: Programmed cell death-1 $(P D-1)$ and its ligands ( $P D-L 1$ and PD-L2) play a critical role as a regulator of immune-system cells, including T cell, natural killer T (NKT), monocytes, dendritic cells (DC), and B cells. Objective: This study aimed to find a possible association between PD-1 (rs11568821, rs2227981, rs2227982), and PD-L1 (rs4143815, rs2890658) variants and Breast Cancer (BC) risk in a sample of southeast Iranian women. Method: The case-control study consisted of 520 individuals, including 260 histologically confirmed BC patients and 260 non-cancer age-matching healthy women as the control group. The Polymerase Chain Reaction-Restriction Fragment Length Polymorphism (PCR-RFLP) and Tetra-Primer Amplification Refractory Mutation System-Polymerase Chain Reaction (T-ARMS-PCR) methods were used for genotyping of PD-1 (rs11568821, rs2227981, rs2227982), and $P D-L 1$ (rs4143815, rs2890658) polymorphisms. Results and Conclusion: Our findings indicated that the $P D-L 1$ rs4143815 (G/C) variant meaningfully reduced the risk of BC. However, the $P D-L 1 \mathrm{rs} 2890658$ variant increased the $\mathrm{BC}$ risk in the AC genotype as well as the A allele. Furthermore, we could not find a meaningful association between $P D-1$ rs11568821, $P D-1$ rs2227981, $P D-1$ rs2227982, and BC. Our team examined the possible association between variants and clinicopathological characteristics, including age, size of tumour, lymph node, histology, grade of tumour, estrogen and progesterone receptors status as well as human growth factor receptor 2 (HER2). Our findings demonstrated that $P D-L 1$ rs4143815, $P D-L 1$ rs $2890658, P D-1$ rs2227982 had a significant association with age. Additionally, we found a significant relation between $P D-1$ rs2227982 variant and tumour size. Statistical analyzes of $P D-1$ rs 2227981 and $P D-1$ rs11568821 variants showed a meaningful relation between tumour grade and tumour stage $(\mathrm{p}=0.006)$, respectively.
\end{abstract}

Keywords: Apoptosis- $P D-L 1-P D-1$ - cancer- polymorphism

Asian Pac J Cancer Prev, 21 (10), 3115-3123

\section{Introduction}

Breast Cancer (BC), the second most frequently diagnosed carcinoma and the primary cause of cancer mortality among women all around the world, is becoming the main concern for public health in all communities (Ferlay et al., 2015). Development of BC begins with the abnormal and rapid division of breast cells, resulting in tumour formation that could invade other breast tissues and spread to other organs (Yu, 2019; Umami et al., 2020) such as brain, lungs, and bones (Eckhardt et al., 2012; Vickers, 2017).

The findings of numerous studies have shown a strong correlation between the susceptibility to BC and factors such as genetic mutation, diet, physical activity, breastfeeding, level of estrogen and progesterone hormones (Jayasekara et al., 2016, Pizot et al., 2016; Anstey et al., 2017; Dall and Britt, 2017; Shiyanbola et al., 2017; Bertoni et al., 2019; McTiernan et al., 2019). However, the leading cause of $\mathrm{BC}$ has yet to be identified.

${ }^{1}$ Department of Clinical Biochemistry, School of Medicine, Zahedan University of Medical Sciences, Zahedan, Iran. ${ }^{2}$ Department of Human Anatomy and Cell Science, Max Rady College of Medicine, Rady Faculty of Health Sciences, University of Manitoba, Winnipeg, MB R3E 3P4, Canada. ${ }^{3}$ Genetics of Non- Communicable Disease Research Center, Zahedan University of Medical Sciences, Zahedan, Iran. ${ }^{4}$ Children and Adolescent Health Research Center, Resistant Tuberculosis Institute, Zahedan University of Medical Sciences, Zahedan, Iran. ${ }^{5}$ Faculty of Medicine, Katowice School of Technology, 40-555 Katowice, Poland. ${ }^{6}$ Autophagy Research Center, Faculty of Medicine, Shiraz University of Medical Sciences, Shiraz, Iran. *For Correspondence: saeid.ghavami@umanitoba.ca 
Genetic mutation, critical factor to cancer susceptibility, are responsible for permanent alternations in DNA and RNA sequences. Single nucleotide polymorphisms (SNPs) are responsible for phenotype variations in populations (Kitts and Sherry 2002). SNPs' could be located in various regions of the human genome, such as in promoters, exons, introns, as well as 5'- and 3' UTRs. Consequently, small changes in these parts might affect the expression of genes and also increase or decrease the vulnerability to certain diseases (Taylor et al., 2001; Bond et al., 2005; Fan et al., 2010; Wu et al., 2014; Schirmer et al., 2016; Hashemi et al., 2020).

Programmed cell death-1 $(P D-1)$ is an immune checkpoint key receptor responsible for maintaining self-tolerance and inhibition of uncontrolled inflammation (Francisco et al., 2010; Hashemi et al., 2019; Hashemi et al., 2020). $P D-1$ is mainly expressed on the surface of several immune system cells (Inman et al., 2007; Keir et al., 2008; Ahmadzadeh et al., 2009; Hashemi et al., 2019). The human $P D-1$ gene is located on chromosome $2 q 27.3$, which consists of two domains, extracellular immunoglobulin $\mathrm{V}$ domain and an intracellular domain containing an inhibitory motif(ITIM) and immune receptor tyrosine-based switch motif (ITSM). Programmed cell death ligand 1 and $2(P D-L 1$ and PD-L2) are two main ligands for $P D-1$ receptor. ITIM is activated by binding $P D-L 1$ or PD-L2 ligands to the $P D-1$ receptor, which could promote inhibitory signals to decrease the activation of $\mathrm{T}$ lymphocytes and cause proliferation (Hashemi et al., 2019).

$P D-L 1$, located at 9p24 chromosome, is one of the transmembrane type 1 glycoproteins. Several studies showed that the upregulation of $P D-L 1$ is a major cause of cancer immune evasion (Yamazaki et al., 2002; Nguyen and Ohashi, 2015; Salmaninejad et al., 2018; Hashemi et al., 2019). Binding the $P D-L 1$ ligand with $P D-1$ receptor can dephosphorylate several kinases, including ZAP70, AKT, PI3K, and ERK-R, which can inhibit IL-2 production on $\mathrm{T}$ cells and cause $\mathrm{T}$ cell proliferation and apoptosis (Zheng and Zhou, 2015; Catakovic et al., 2017). The abnormal expression of PD-Ls on the cell lines or tissues of several tumours, including cervical cancer (Karim et al., 2009), gastric carcinoma (Ohigashi et al., 2005), and breast cancer (Ghebeh et al., 2006) have been comprehensively investigated.

Genetic polymorphism of $P D-L 1$ and $P D-1$ were reported in several malignancies (Haghshenas et al., 2011; Hua et al., 2011; Qiu et al., 2014; Ma et al., 2015; Dougan, 2017; Haghshenas et al., 2017; Juchem et al., 2018; Kuol et al., 2018; Tan et al., 2018; Zhang et al., 2018). Therefore, in the current investigation, our team evaluated the correlation between $P D-1$ (rs11568821, rs2227981, rs2227982) and $P D-L 1$ (rs4143815, rs2890658) and BC susceptibility in a sample of southeast Iranian women.

\section{Materials and Methods}

\section{Patients}

Our case-control study was performed on 520 individuals comprising 260 histologically confirmed $\mathrm{BC}$ patients, and 260 control healthy individuals within the same age group. The protocol of this study has been designed based on previous investigations (Danesh et al., 2018; Hashemi et al., 2018). The institutional review board approved the current research at Zahedan University of Medical Sciences (IR.ZAUMS.REC.1397.386). Proper consent was obtained from all participants. The genomic DNA samples were extracted using the salting-out method and were collected in separate special tubes containing EDTA (Hashemi et al., 2013).

\section{Genotyping}

Polymerase Chain Reaction-Restriction Fragment Length Polymorphism (PCR-RFLP) method was used for genotyping the $P D-L 1$ rs2890658, $P D-1$ rs11568821, $P D-1$ rs2227981 and $P D-1$ rs2227982 polymorphisms. For identification of the $P D-L 1$ rs 4143815 variant, we used Tetra-Primer Amplification Refractory Mutation System-Polymerase Chain Reaction (T-ARMS-PCR) technique. The procedure used for this investigation, previously designed and testified by Hashemi's lab, is as follow (Hashemi et al., 2012; Hassanzarei et al., 2017):

1 . The volume for assembling the reaction solution in each PCR tube for RFLP-PCR and T-ARMS-PCR methods are accessible in Table 1.

2. Primes sequences used for the detection of $P D-1$ and $P D-L 1$ are presented in Table 2.

3. PCR thermal cycling conditions used for amplification of $P D-1$ and $P D-L 1$ polymorphisms, are listed in Table 3.

4. Corresponding restriction endonucleases used for the digestion of PCR products are mentioned in Table 2.

5. UV transilluminator was used to visualize the fragments digested and separated by agarose gel electrophoresis. Briefly, for $P D-1$ rs11568821, the PstI enzyme digested the A allele and produced a 93 base pair (bp) and 197 bp pattern. However, the $G$ allele was undigested (290 bp fragment) Figure 1A. Regarding $P D-1$ rs2227981, we used the PvuII restriction enzyme to digest the $\mathrm{T}$ allele to a $74 \mathrm{bp}$ and $133 \mathrm{bp}$ pattern. Nevertheless, the $\mathrm{C}$ allele remained undigested (207 bp fragment) Figure 1B. For $P D-1$ rs2227982, we used the BceAI restriction enzyme to digest the $\mathrm{C}$ allele to $29 \mathrm{bp}$ and 145 bp pattern. However, the $\mathrm{T}$ allele remained undigested (174 bp fragment) Figure 2A. The PD-L1 rs $2890658 \mathrm{C}$ allele was digested by HaeIII and made a 25 bp and 226 bp pattern, while the A allele stayed undigested (251 bp fragment) Figure 2B.

We used the T-ARMS-PCR method for genotyping the PD-L1 rs4143815 (Ye, Dhillon et al. 2001, Hashemi, Moazeni-roodi et al. 2012). In this technique, two external primers (forward outer and reverse outer) and two allele-specific internal primers (forward inner and reverse inner) were designed. Three bands were produced; $322 \mathrm{bp}$ for control band, and two $203 \mathrm{bp}$ and $176 \mathrm{bp}$ bands related to $\mathrm{C}$ and $\mathrm{G}$ allele, respectively Figure 3 . Furthermore, we sequenced the $P D-L 1$ rs4143815 to validate our genotyping and results in Figure 4.

\section{Statistical analysis}

All of the statistical data was carried out by using computer software Statistical Package for Social 
Sciences (SPSS) (ver. 24.0). The correlation between $P D-1$ (rs11568821, rs2227981, rs2227982) and PD-L1 (rs4143815, rs2890658) SNPs and BC susceptibility were calculated with Unconditional logistic regression analysis. To estimate the Hardy-Weinberg equilibrium (HWE) among the controls, we used the $\chi 2$ test. We considered the p-value less than $0.05(\mathrm{P}<0.05)$ to be statistically significant.

\section{Results}

The current case-control investigation included 520 participants. The patient group consisted of $260 \mathrm{BC}$ patients with an average age group of $48.09 \pm 10.59$, and the control group consisted of 260 healthy females with an average age group of $46.26 \pm 10.72$. There was no significant statistical difference between the age groups $(\mathrm{p}=0.052)$. Frequency of alleles and genotyping of PD-1 (rs11568821, rs2227981, rs2227982) and PD-L1 (rs4143815, rs2890658) polymorphisms among cases and controls are presented in Table 4.
Our results showed that $P D-L 1$ rs4143815 (G/C) variant significantly reduced the risk of $\mathrm{BC}$ in homozygous $(\mathrm{OR}=0.52,95 \% \mathrm{CI}=0.28-0.96, \mathrm{P}=0.049, \mathrm{GG}$ vs $\mathrm{CC})$, recessive $(\mathrm{OR}=0.44,95 \% \mathrm{CI}=0.26-0.77, \mathrm{P}=0.006, \mathrm{GG}$ vs $\mathrm{CG}+\mathrm{CC})$ genetic models. Regarding the $P D-L 1$ rs2890658 C/A polymorphism, our results show that $P D-L 1$ rs2890658 significantly increased the risk of BC in heterozygous $(\mathrm{OR}=2.44,95 \% \mathrm{CI}=1.71-3.46, \mathrm{p}<0.0001$, $\mathrm{CA}$ vs $\mathrm{CC})$, dominant $(\mathrm{OR}=2.48,95 \% \mathrm{CI}=1.74-3.51$, $\mathrm{p}<0.0001, \mathrm{CA}+\mathrm{AA}$ vs $\mathrm{CC})$, and A allele $(\mathrm{OR}=1.87$, $95 \% \mathrm{CI}=1.41-2.48, \mathrm{p}<0.0001$, A vs $\mathrm{C})$ genetic models. We could not find a significant correlation between $P D-1$ rs11568821, $P D-1$ rs2227981, $P D-1$ rs2227982 and variants and the risk of $\mathrm{BC}$.

Furthermore, our team examined the possible association between variants and clinicopathological characteristics, including age, size of the tumour, lymph node, histology, the grade of tumour, estrogen and progesterone receptors status as well as human growth factor receptor 2 (HER2) Table 5. Our findings demonstrated that $P D-L 1$ rs4143815, $P D-L 1$ rs2890658,

Table 1. The Volumes for Assembling the Reaction Solution in Each PCR tube for the Detection of PD-1 and $P D-L 1$ Polymorphisms

\begin{tabular}{|c|c|c|c|c|c|c|c|}
\hline Polymorphisms & $\begin{array}{c}\text { Reverse } \\
\text { Inner Primer }\end{array}$ & $\begin{array}{c}\text { Forward } \\
\text { Inner Primer }\end{array}$ & $\begin{array}{c}\text { Forward } \\
\text { Outer Primer }\end{array}$ & $\begin{array}{c}\text { Reverse } \\
\text { Outer Primer }\end{array}$ & $\begin{array}{l}2 \mathrm{X} \text { Taq } \\
\text { master mix }\end{array}$ & $\mathrm{H}_{2} \mathrm{O}$ & DNA \\
\hline $\begin{array}{l}P D-L 1 \\
\text { Rs4143815 } \\
\text { Tetra-ARMS }\end{array}$ & $1 \mu 1$ & $1 \mu 1$ & $1 \mu 1$ & $1 \mu l$ & $8 \mu 1$ & $6 \mu \mathrm{l}$ & $1 \mu 1$ \\
\hline $\begin{array}{l}P D-L 1 \\
\text { Rs2890658 } \\
\text { RFLP }\end{array}$ & $1 \mu 1$ & $1 \mu 1$ & - & - & $8 \mu \mathrm{l}$ & $6 \mu l$ & $1 \mu 1$ \\
\hline $\begin{array}{l}P D-1 \\
\text { Rs11568821 } \\
\text { RFLP }\end{array}$ & $1 \mu 1$ & $1 \mu 1$ & - & - & $8 \mu 1$ & $6 \mu 1$ & $1 \mu 1$ \\
\hline $\begin{array}{l}P D-1 \\
\text { Rs2227981 } \\
\text { RFLP }\end{array}$ & $1 \mu 1$ & $1 \mu 1$ & - & - & $8 \mu 1$ & $6 \mu 1$ & $1 \mu 1$ \\
\hline $\begin{array}{l}P D-1 \\
\text { Rs2227982 } \\
\text { RFLP }\end{array}$ & $1 \mu 1$ & $1 \mu 1$ & - & - & $8 \mu 1$ & $6 \mu \mathrm{l}$ & $1 \mu 1$ \\
\hline
\end{tabular}

(1A)

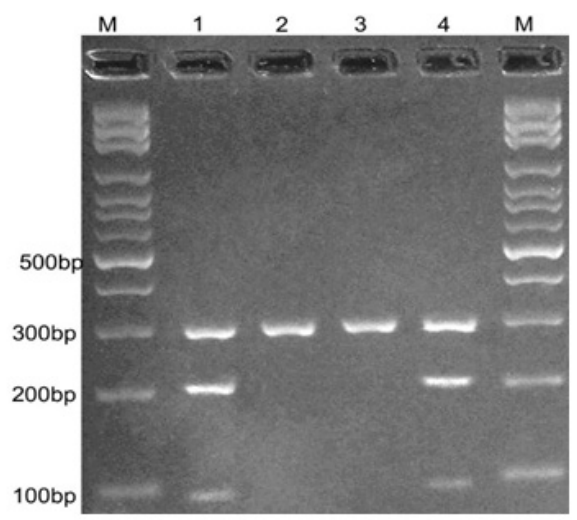

(1B)

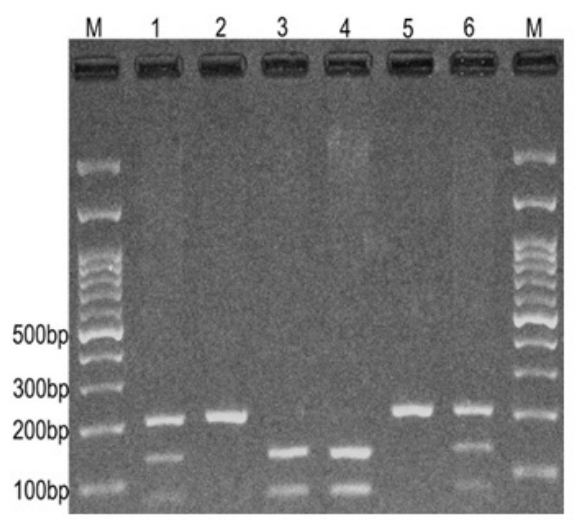

Figure 1. (1A) electrophoresis pattern of the PCR-RFLP method for the detection of PD-1rs11568821(G/A) polymorphism. M: DNA marker; Lanes 1 and 4: GA; Lanes 2 and 3: GG (1B): Photograph of electrophoresis pattern of the PCR-RFLP method for detection of PD-1 rs2227981(C/T) polymorphism. M, DNA marker; Lanes 1 and 6, CT; Lanes 2 and 5, CC; lanes 3 and 4, TT 
Table 2. The Pprimers Used for Detection of $P D-1$ and $P D-L 1$ Polymorphism

\begin{tabular}{|c|c|c|c|}
\hline Polymorphisms & Primer sequence $\left(5^{\prime}->3^{\prime}\right)$ & Restriction Enzyme & Fragment (bp) \\
\hline $\begin{array}{l}P D-L 1 \\
\text { rs4143815 }\end{array}$ & $\begin{array}{l}\text { FO: CTGTGACAGGGAGAAAGGATACTTCTG } \\
\text { RO: AGCAAGTTTAGTTTGGCGACAAAATTGT } \\
\text { FI: TTTGCCTCCACTCAATGCCTCAATATC } \\
\text { RI: AACACTGAGACTCTCAGTCATGCAGAATAC }\end{array}$ & -- & $\begin{array}{l}\text { Allele } \mathrm{G}=176 \mathrm{bp} \\
\text { Allele } \mathrm{C}=203 \mathrm{bp} \\
\text { Control }=322 \mathrm{bp}\end{array}$ \\
\hline $\begin{array}{l}P D-L 1 \\
\text { rs } 2890658\end{array}$ & $\begin{array}{l}\text { F: GCAAGAGGAAGTGAAATAATCAAG } \\
\text { R: GATACCTGTGTTAAAATGGGAACAG }\end{array}$ & HaeIII & $\begin{array}{c}\text { Allele } A=251 \mathrm{bp} \\
\text { Allele } \mathrm{C}=226+25 \mathrm{bp}\end{array}$ \\
\hline $\begin{array}{l}P D-1 \\
\text { rs11568821 }\end{array}$ & $\begin{array}{l}\text { F: CTCACATTCTATTATAGCCAGGACC } \\
\text { R: TAAGATAAGAAATGACCAAGCCCAC }\end{array}$ & PstI & $\begin{array}{c}\text { Allele } \mathrm{G}=290 \mathrm{bp} \\
\text { Allele } \mathrm{A}=197+93 \mathrm{bp}\end{array}$ \\
\hline $\begin{array}{l}P D-1 \\
\text { rs } 2227981\end{array}$ & $\begin{array}{l}\text { F: TGAGCAGACGGAGTATGCC } \\
\text { R: CTGAGGAAATGCGCTGACC }\end{array}$ & PvuII & $\begin{array}{l}\text { Allele } \mathrm{C}=207 \mathrm{bp} \\
\text { Allele } \mathrm{T}=133+74 \mathrm{bp}\end{array}$ \\
\hline $\begin{array}{l}P D-1 \\
\text { rs2227982 }\end{array}$ & $\begin{array}{l}\text { F: TGACTCCCTCTCCCTTTCTCCTC } \\
\text { R: GCCCATTCCGCTAGGAAAGA }\end{array}$ & BceAI & $\begin{array}{c}\text { Allele } \mathrm{T}=174 \mathrm{bp} \\
\text { Allele } \mathrm{C}=145+29 \mathrm{bp}\end{array}$ \\
\hline
\end{tabular}

(2A)

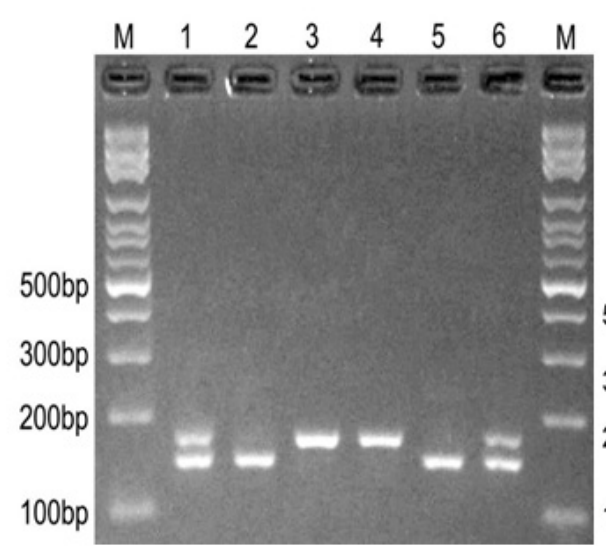

(2B)

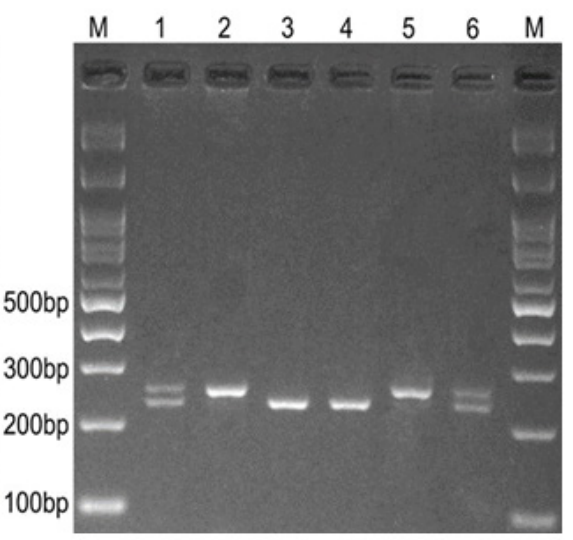

Figure 2. (2A). Electrophoresis pattern of the PCR-RFLP method for the detection of PD-1rs2227982(C/T) polymorphism. M: DNA marker; Lanes 1 and 6: CT; Lanes 2 and 5: CC; lanes 3 and 4: TT. (2B) electrophoresis pattern of the PCR-RFLP method for the detection of PD-L1rs2890658(C/A) polymorphism. M: DNA marker; Lanes 1 and 6: CA; Lanes 2 and 5: AA; lanes 3 and 4: CC

and $P D-1 \mathrm{rs} 2227982$ had a significant correlation with age $(\mathrm{p}=0.005, \mathrm{p}=0.046, \mathrm{p}<0.001)$. Additionally, we found a significant correlation between $P D-1$ rs2227982 variant and tumour size $(\mathrm{p}=0.049)$. Statistical analyzes of $P D-1$ rs2227981 and $P D-1$ rs11568821 variants showed the meaningful relation between tumor grade $(p=0.049)$ and

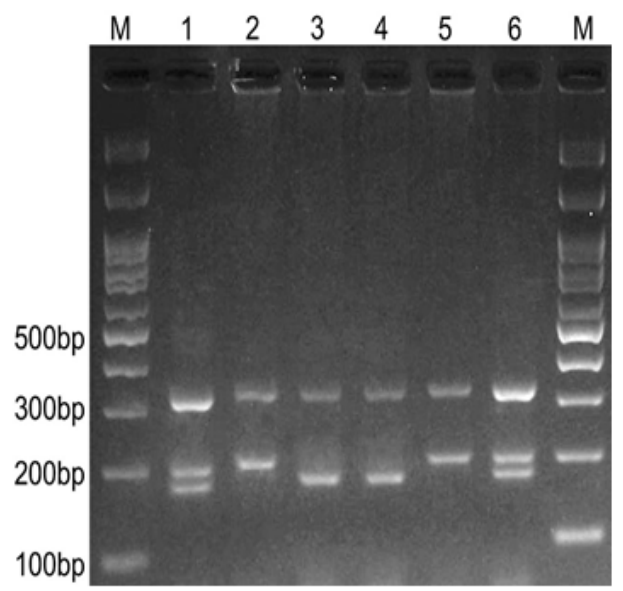

Figure 3. Electrophoresis Pattern of the T-ARMS Method for the Detection of $P D-L 1 \mathrm{rs} 4143815(\mathrm{G} / \mathrm{C})$ Polymorphism. M, DNA marker; Lanes 1 and 6, GC; Lanes 2 and 5, CC; lanes 3 and 4, GG

3118 Asian Pacific Journal of Cancer Prevention, Vol 21
A $\quad 100 \quad \downarrow \quad 120$ AATGCCTCAATTTGTTTTCTGCATGAC

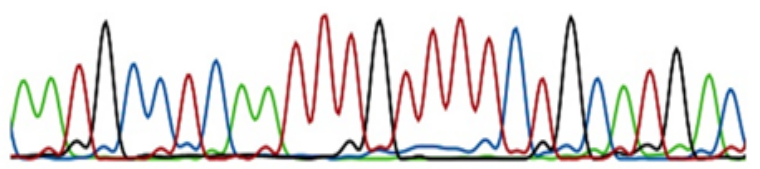

B

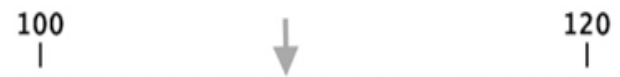

AATGCCTCAATTTNTTTTCTGCATGAC

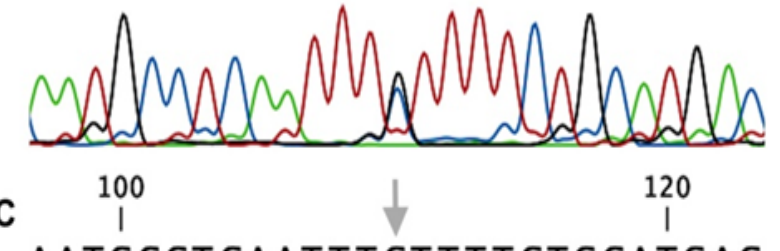

AATGCCTCAATTTCTTTTCTGCATGAC

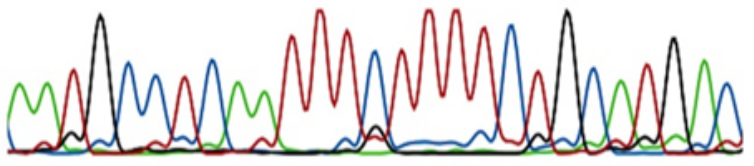

Figure 4. Sequencing of $P D-L 1$ rs4143815 
Table 3. PCR Thermal Cycling Conditions for Amplification of $P D-1$ and $P D-L$ Polymorphisms

\begin{tabular}{lccccccc}
\hline polymorphism & \multicolumn{2}{c}{ Denaturation } & \multicolumn{2}{c}{ Annealing } & \multicolumn{2}{c}{ Extension } & Cycles \\
& Time & Temp & Time & Temp & Time & temp & \\
\hline$P D-L 1$ rs4143815 & $30 \mathrm{~s}$ & $95^{\circ} \mathrm{C}$ & $30 \mathrm{~s}$ & $58^{\circ} \mathrm{C}$ & $30 \mathrm{~s}$ & $72^{\circ} \mathrm{C}$ & 30 \\
$P D-L 1$ rs2890658 & $30 \mathrm{~s}$ & $95^{\circ} \mathrm{C}$ & $30 \mathrm{~s}$ & $59^{\circ} \mathrm{C}$ & $30 \mathrm{~s}$ & $72^{\circ} \mathrm{C}$ & 30 \\
$P D-1$ rs11568821 & $30 \mathrm{~s}$ & $95^{\circ} \mathrm{C}$ & $30 \mathrm{~s}$ & $64^{\circ} \mathrm{C}$ & $30 \mathrm{~s}$ & $72^{\circ} \mathrm{C}$ & 30 \\
$P D-1$ rs2227981 & $30 \mathrm{~s}$ & $95^{\circ} \mathrm{C}$ & $30 \mathrm{~s}$ & $61^{\circ} \mathrm{C}$ & $30 \mathrm{~s}$ & $72^{\circ} \mathrm{C}$ & 30 \\
$P D-1$ rs2227982 & $30 \mathrm{~s}$ & $95^{\circ} \mathrm{C}$ & $30 \mathrm{~s}$ & $62^{\circ} \mathrm{C}$ & $30 \mathrm{~s}$ & $72^{\circ} \mathrm{C}$ & 30 \\
\hline
\end{tabular}

Table 4. The Association of $P D-1$ and $P D-L 1$ Polymorphisms and Breast Cancer Risk

\begin{tabular}{|c|c|c|c|}
\hline PD-L1 Polymorphisms & $\begin{array}{l}\text { Case } \\
\mathrm{n}(\%)\end{array}$ & $\begin{array}{c}\text { Control } \\
\mathrm{n}(\%)\end{array}$ & OR $(95 \% \mathrm{CI})$ \\
\hline \multicolumn{4}{|l|}{$P D-L 1$ rs 4143815} \\
\hline \multicolumn{4}{|l|}{ Codominant } \\
\hline $\mathrm{CC}$ & $79(30.4)$ & $84(32.3)$ & 1 \\
\hline CG & $161(61.9)$ & $135(51.9)$ & $1.27(0.87-1.86)$ \\
\hline GG & $20(7.7)$ & $41(15.8)$ & $0.52(0.28-0.96)$ \\
\hline \multicolumn{4}{|l|}{ Dominant } \\
\hline $\mathrm{CC}$ & $79(30.4)$ & $84(32.3)$ & 1 \\
\hline $\mathrm{CG}+\mathrm{GG}$ & $181(69.6)$ & $176(67.7)$ & $1.09(0.75-1.60)$ \\
\hline \multicolumn{4}{|l|}{ Recessive } \\
\hline $\mathrm{CG}+\mathrm{CC}$ & $240(92.3)$ & $219(84.2)$ & 1 \\
\hline GG & $20(7.7)$ & $41(15.8)$ & $0.44(0.26-0.77)$ \\
\hline \multicolumn{4}{|l|}{ Allele } \\
\hline $\mathrm{C}$ & $319(61.35)$ & $303(58.27)$ & 1 \\
\hline G & $201(38.65)$ & $217(41.73)$ & $0.88(0.68-1.13)$ \\
\hline \multicolumn{4}{|l|}{$P D-L 1$ rs 2890658} \\
\hline \multicolumn{4}{|l|}{ Codominant } \\
\hline $\mathrm{CC}$ & $101(38.9)$ & $159(61.1)$ & 1 \\
\hline $\mathrm{CA}$ & $155(59.6)$ & $100(38.5)$ & $2.44(1.71-3.46)$ \\
\hline AA & $4(1.5)$ & $1(0.4)$ & $6.30(0.69-57.14)$ \\
\hline \multicolumn{4}{|l|}{ Dominant } \\
\hline $\mathrm{CC}$ & $101(38.9)$ & $159(61.1)$ & 1 \\
\hline $\mathrm{CA}+\mathrm{AA}$ & $159(61.1)$ & $101(38.9)$ & $2.48(1.74-3.51)$ \\
\hline \multicolumn{4}{|l|}{ Recessive } \\
\hline $\mathrm{CC}+\mathrm{CA}$ & $256(98.5)$ & $259(99.6)$ & 1 \\
\hline AA & $4(1.5)$ & $1(0.4)$ & $4.05(0.45-36.45)$ \\
\hline \multicolumn{4}{|l|}{ Allele } \\
\hline $\mathrm{C}$ & $357(68.7)$ & $418(80.3)$ & 1 \\
\hline $\mathrm{A}$ & $163(31.3)$ & $102(19.7)$ & $1.87(1.41-2.48)$ \\
\hline \multicolumn{4}{|l|}{ PD-1 rs 11568821} \\
\hline \multicolumn{4}{|l|}{ Codominant } \\
\hline GG & $234(90.0)$ & $245(94.2)$ & 1 \\
\hline GA & $26(10.0)$ & $15(5.8)$ & $1.81(0.95-3.39)$ \\
\hline AA & 0 & 0 & \\
\hline \multicolumn{4}{|l|}{ Allele } \\
\hline G & $494(95.0)$ & $505(97.1)$ & 1 \\
\hline A & $26(5.0)$ & $15(2.9)$ & $1.77(0.95-3.35)$ \\
\hline \multicolumn{4}{|l|}{ PD-1 rs2227981 } \\
\hline \multicolumn{4}{|l|}{ Codominant } \\
\hline $\mathrm{CC}$ & $113(43.5)$ & $130(50.0)$ & 1 \\
\hline CT & $139(53.4)$ & $125(48.1)$ & $1.28(0.90-1.82)$ \\
\hline $\mathrm{TT}$ & $8(3.1)$ & $5(1.9)$ & $1.84(0.53-5.78)$ \\
\hline
\end{tabular}

Table 4. Continued

\begin{tabular}{|c|c|c|c|}
\hline PD-L1 Polymorphisms & $\begin{array}{l}\text { Case } \\
\mathrm{n}(\%)\end{array}$ & $\begin{array}{l}\text { Control } \\
\text { n (\%) }\end{array}$ & OR $(95 \% \mathrm{CI})$ \\
\hline \multicolumn{4}{|l|}{ Dominant } \\
\hline $\mathrm{CC}$ & $113(43.5)$ & $130(50.0)$ & 1 \\
\hline $\mathrm{CT}+\mathrm{TT}$ & $147(56.5)$ & $130(50.0)$ & $1.30(0.93-1.83)$ \\
\hline \multicolumn{4}{|l|}{ Recessive } \\
\hline $\mathrm{CC}+\mathrm{CT}$ & 252 (96.9) & $255(98.1)$ & 1 \\
\hline TT & $8(3.1)$ & $5(1.9)$ & $1.62(0.51-4.44)$ \\
\hline \multicolumn{4}{|l|}{ Allele } \\
\hline $\mathrm{C}$ & $365(70.2)$ & $385(74.0)$ & 1 \\
\hline $\mathrm{T}$ & $155(29.8)$ & $135(26.0)$ & $1.21(0.93-1.59)$ \\
\hline \multicolumn{4}{|l|}{ PD-1 rs2227982 } \\
\hline \multicolumn{4}{|l|}{ Codominant } \\
\hline $\mathrm{CC}$ & $211(81.2)$ & $200(76.9)$ & 1 \\
\hline $\mathrm{CT}$ & $47(18.1)$ & $56(21.5)$ & $0.79(0.52-1.23)$ \\
\hline TT & $2(0.7)$ & $4(1.6)$ & $0.47(0.09-2.05)$ \\
\hline \multicolumn{4}{|l|}{ Dominant } \\
\hline $\mathrm{CC}$ & $211(81.2)$ & $200(76.9)$ & 1 \\
\hline $\mathrm{CT}+\mathrm{TT}$ & $49(18.8)$ & $60(23.1)$ & $0.77(0.50-1.18)$ \\
\hline \multicolumn{4}{|l|}{ Recessive } \\
\hline $\mathrm{CC}+\mathrm{CT}$ & $258(99.3)$ & $256(98.4)$ & 1 \\
\hline TT & $2(0.7)$ & $4(1.6)$ & $0.50(0.09-2.15)$ \\
\hline \multicolumn{4}{|l|}{ Allel } \\
\hline $\mathrm{C}$ & $469(90.2)$ & $456(87.7)$ & 1 \\
\hline $\mathrm{T}$ & $51(9.8)$ & $64(12.3)$ & $0.77(0.53-1.15)$ \\
\hline
\end{tabular}

tumor stage $(\mathrm{p}=0.006)$.

\section{Discussion}

Our current study aimed to examine the possible association between $P D-1$ (rs11568821, rs2227981, rs2227982), PD-L1 (rs4143815, rs2890658) polymorphisms and susceptibility to $\mathrm{BC}$ in a sample of southeast Iranian women. Recent investigations showed that $P D-1$ and its ligand $(P D-L 1)$ play a critical role in regulation of immune system cells' function (Inman et al., 2007; Keir et al., 2008). Several studies showed that there is a meaningful association between the abnormal expression of $P D-1 / \mathrm{PD}-\mathrm{Ls}$ and susceptibility to $\mathrm{BC}$ (Haghshenas et al., 2011, Hua et al., 2011; Ren et al., 2016). Thus, we considered the $P D-1 / P D-L 1$ pathway as a strong potential candidate for susceptibility to $\mathrm{BC}$ in a sample of southeast Iranian women. 


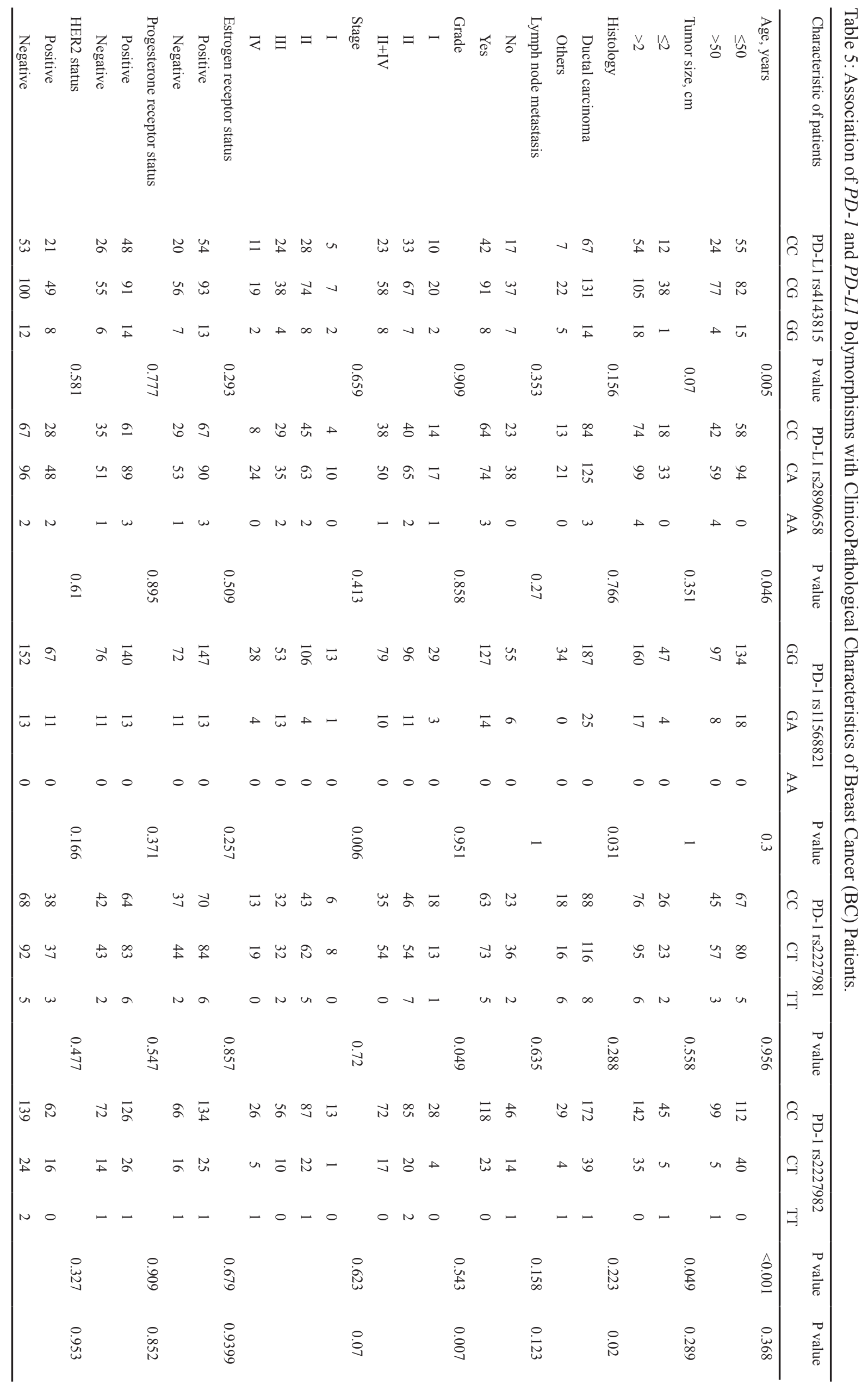


Our result proposed that the GG genotype of the $P D$ $L 1$ rs4143815 variant significantly decreased the risk of $\mathrm{BC}$ in our study. We also found that $P D-L 1$ rs4143815 had a significant correlation with age (Table 5). Currently, there is still controversy about the direct function of $P D$ L1 rs4143815 in cancers. Several studies suggested that abnormal expression of $P D-L 1$ rs4143815 increased the susceptibility risk to gastric cancer (Wang et al., 2013), ovarian cancer (Tan et al., 2018), and hepatocellular (HCC) carcinoma (Xie et al., 2018) in the Chinese population. However, there was no relation between $P D-L 1$ rs4143815 and susceptibility or protection to esophageal squamous cell carcinoma (Zhou et al., 2016) and colorectal cancer (Catalano et al., 2018).

Regarding the $P D-L 1$ rs 2890658 C/A polymorphism, our results showed that the AC genotype and A allele of $P D-L 1$ rs2890658 significantly increased the risk of BC. Similarly, Chen et al., (2014) showed that AC genotype and A allele increased the risk of non-small cell lung cancer (NSCLC) susceptibility in a Chinese population. Furthermore, $P D-L 1$ rs2890658 was also recognized as a risk factor in NSCLC in two other studies of the Chinese population (Cheng et al., 2015; Ma et al., 2015). However, there is still controversy about the primary role of $P D-L 1$ rs2890658 in cancer susceptibility. Xie et al., (2018) found that $P D-L 1$ rs 2890658 was not associated with HCC in a Chinese population. We also found that $P D-L 1$ rs 2890658 had a significant relationship with age (Table 5).

$P D-1$ rs11568821 (PD-1.3) is located on intron 4 of the $P D-1$ human gene. A "G" to "A" alteration might affect the runt-related transcription factor 1 (RUNX1) binding site (Prokunina et al., 2002). Our findings showed no meaningful differences in genotype and allele frequencies of $P D-1$ rs 11568821 variant and $\mathrm{BC}$ risk. Therefore, we concluded that RUNX1 activity was not correlated with $\mathrm{BC}$ risk in our study. Similar to our result, Haghshenas (2011) reported that the $P D-1$ rs11568821 variant was not associated with $\mathrm{BC}$ and thyroid cancer in a sample of south Iranian females (Haghshenas et al., 2011). Furthermore, numerous investigations showed that $P D-1$ rs11568821 was not associated with NSCLC (Ma et al., 2015), Leukemia (Ramzi et al., 2018), colorectal cancer (Yousefi et al., 2013), Benign Brain Tumors (Namavar et al., 2017) and hepatocellular carcinoma (Bayram et al., 2012). We also found that there is a significant association between $P D-1$ rs 11568821 and the stage of tumour in BC patients (Table 5).

In the current research, we could not find any correlation between PD-1 rs2227981 and BC. Similarly, numerous studies all around the world could not confirm a significant association between $P D-1$ rs2227981 and susceptibility or protection to BC (Haghshenas et al., 2011), colorectal cancer (Savabkar et al., 2013), NSCLC (Ma et al., 2015) and epithelial ovarian cancer (Li et al., 2016). However, $P D-1$ rs2227981 variant was recognized as a risk factor in several cancers including, cervical cancer (Li et al., 2016), BC (Hua et al., 2011), gastric cancer (Savabkar et al., 2013) and thyroid cancer (Haghshenas et al., 2017). Our findings also showed that $P D-1$ rs 11568821 is significantly associated with tumour grade (Table 5).

In the current study, we also confirmed that there was not any significant correlation between $P D-1$ rs2227982 and BC. Similarly, several investigations were not able to find any association between $P D-1$ rs2227982 variant and susceptibility or protection to BC (Hua et al., 2011), esophageal cancer (ESCC) (Qiu et al., 2014) and non-small cell lung cancer (NSCLC) (Ma et al., 2015). Despite our results, the $P D-1$ rs2227982 variant was recognized as a protective factor in esophagogastric junction adenocarcinoma (Tang et al., 2017). However, the result of many studies revealed that $P D-1$ rs2227982 variant was a risk factor in several cancers including, leukemia(Ramzi et al., 2018), gastric cardia adenocarcinoma (Tang et al., 2017), esophageal squamous cell carcinoma (Zhou et al., 2016) and ovarian cancer (Tan et al., 2018). Our findings also demonstrated that $P D-1$ rs2227982 was significantly associated with age in the patient group (Table 5).

In conclusion, our current study suggested that two functional polymorphisms $P D-L 1$ rs4143815 and $P D-L 1$ rs2890658 were associated with BC protection and risk in a sample of southeast Iranian women. The previous investigations have shown that $P D-1$ and $P D-L 1 / \mathrm{PD}-\mathrm{L} 2$ belong to the family of immune checkpoint proteins which could induce proliferation and apoptosis in $\mathrm{T}$ Cells of cancer patients and causes cancer development (Li et al., 2016; Sacher and Gandhi, 2016, Hashemi et al., 2019). Thus, genetic variation in $P D-L 1$ rs4143815 and $P D-L 1$ rs 2890658 could be a possible prognostic marker for the prediction of BC susceptibility and development. Additionally, we could not find a meaningful association between $P D-1$ rs11568821, PD-1 rs2227981, $P D-1$ rs2227982 variants and $\mathrm{BC}$ risk or protection. Inconsistency in the results of several investigations might be associated with different genetic backgrounds, environmental factors, and the sample size of the study. Further investigations and larger sample sizes are needed to clarify the primary function of $P D-1$ (rs11568821, rs2227981, rs2227982), PD-L1 (rs4143815, rs2890658) polymorphisms and BC susceptibility.

\section{Acknowledgments}

\section{Funding}

Our project was supported by Zahedan University of Medical Sciences, Zahedan, Iran, as a dissertation grant (9109\#SHK).

\section{Authors Contributions}

M. Hashemi, H. Sattarifard, S. Sarabandi, S. Karami, M. Kiumarsi, involved in conceptualization, data collection, validation, statistical analysis and manuscript writing (first draft); S. Ghavami and R. Bahari, and M. Taheri formally analyzed and finalized the manuscript. S. Karami and S. Sarabandi collected the patient's samples, did the benchwork. S. Ghavami led the team to finalize the project.

"The raw data supporting the conclusions of this manuscript will be made available by the authors, without undue reservation, to any qualified researcher. Requests to access the datasets should be directed to "saeid.ghavami@ umanitoba.ca".

We would like to dedicate this article to the late Asian Pacific Journal of Cancer Prevention, Vol $213 \mathbf{3 1 2 1}$ 
Professor Mohammad Hashemi, who passed away during the preparation and submission of this work. He was a pioneer in genetic studies.

\section{References}

Ahmadzadeh M, Johnson LA, Heemskerk B, et al (2009). Tumor antigen-specific CD8 T cells infiltrating the tumor express high levels of $P D-1$ and are functionally impaired. $J \mathrm{Am} \mathrm{Soc}$ Hematol, 114, 1537-44.

Anstey EH, Shoemaker ML, Barrera CM, et al (2017). Breastfeeding and breast cancer risk reduction: implications for black mothers. Am J Prev Med, 53, 40-6.

Bayram S, Akkız H, Ülger Y, et al (2012). Lack of an association of programmed cell death-1 PD1. 3 polymorphism with risk of hepatocellular carcinoma susceptibility in Turkish population: a case-control study. Gene, 511, 308-13.

Bertoni N, de Souza MC, Crocamo S, Szklo M, de Almeida LM (2019). Is a family history of the breast cancer related to women's cancer prevention behaviors?. Int J Behav Med, 26, 85-90.

Bond GL, Hu W, Levine A (2005). A single nucleotide polymorphism in the MDM2 gene: from a molecular and cellular explanation to clinical effect. Cancer Res, $\mathbf{6 5}$, 5481-4.

Catakovic K, Klieser E, Neureiter D, Geisberger R (2017). T cell exhaustion: from pathophysiological basics to tumor immunotherapy. Cell Commun Signal, 15, 1-16.

Catalano C, da Silva Filho MI, Frank C, et al (2018). "Investigation of single and synergic effects of NLRC5 and $P D-L 1$ variants on the risk of colorectal cancer. PLoS One, 13, e0192385.

Chen Yb, Mu Cy, Chen C, Huang JA (2014). Association between single nucleotide polymorphism of PD-L1 gene and non-small cell lung cancer susceptibility in a $\mathrm{C}$ hinese population. Asia Pac J Clin Oncol, 10, 1-6.

Cheng S, Zheng J, Zhu J, et al (2015). PD-L1 gene polymorphism and high level of plasma soluble $P D-L 1$ protein may be associated with non-small cell lung cancer. Int J Biol Marker, 30, 364-8.

Dall GV, Britt KL (2017). Estrogen effects on the mammary gland in early and late life and breast cancer risk. Front Oncol, 7, 110.

Danesh H, Hashemi M, Bizhani F, Hashemi SM, Bahari G (2018). Association study of miR-100, miR-124-1, miR-2182, miR-301b, miR-605, and miR-4293 polymorphisms and the risk of breast cancer in a sample of Iranian population. Gene, 647, 73-8.

Dougan M (2017). Checkpoint blockade toxicity and immune homeostasis in the gastrointestinal tract. Front Immunol, 8, 1547.

Eckhardt BL, Francis PA, Parker BS, Anderson RL (2012). "Strategies for the discovery and development of therapies for metastatic breast cancer. Nat Rev Drug Discov, 11, 479-97.

Fan H, Liu D, Qiu X, et al (2010). A functional polymorphism in the DNA methyltransferase-3A promoter modifies the susceptibility in gastric cancer but not in esophageal carcinoma. BMC Med, $8,12$.

Ferlay J, Soerjomataram I, Dikshit R, et al (2015). "Cancer incidence and mortality worldwide: sources, methods and major patterns in GLOBOCAN 2012. Int J Cancer, 136, 359-86.

Francisco LM, Sage PT, Sharpe AH (2010). The PD-1 pathway in tolerance and autoimmunity. Immunol Rev, 236, 219-42.

Ghebeh H, Mohammed S, Al-Omair A, et al (2006). The B7-H1 $(P D-L 1) \mathrm{T}$ lymphocyte-inhibitory molecule is expressed in breast cancer patients with infiltrating ductal carcinoma: correlation with important high-risk prognostic factors. Neoplasia, 8, 190.

Haghshenas M, Dabbaghmanesh M, Miri A, Ghaderi A, Erfani $\mathrm{N}$ (2017). Association of PDCD1 gene markers with susceptibility to thyroid cancer. $J$ Endocrinol Invest, $\mathbf{4 0 ,}$ 481-6.

Haghshenas MR, Dabbaghmanesh MH, Miri A, Ghaderi A and Erfani N (2017). Association of PDCD1 gene markers with susceptibility to thyroid cancer. $J$ Endocrinol Invest, 40, 481-6.

Haghshenas MR, Naeimi S, Talei A, Ghaderi A, Erfani N (2011). Program death 1 (PD1) haplotyping in patients with breast carcinoma. Mol Biol Rep, 38, 4205-10.

Hashemi M, Aftabi S, Moazeni-Roodi A, et al (2020). "Association of CASP8 polymorphisms and cancer susceptibility: A meta-analysis. Eur J Pharmacol, 881, 173201.

Hashemi M, Bojd HH, Nasab EE, et al (2013). Association of adiponectin rs1501299 and rs266729 gene polymorphisms with nonalcoholic fatty liver disease. Hepat Mon, 13.

Hashemi M, Karami S, Sarabandi S, et al (2019). Association between $P D-1$ and $P D-L 1$ polymorphisms and the risk of cancer: A meta-analysis of case-control studies. Cancer, 11.

Hashemi M, Moazeni-roodi A, Bahari A, Taheri M (2012). A tetra-primer amplification refractory mutation system-polymerase chain reaction for the detection of rs8099917 IL28B genotype. Nucleos Nucleot Nucl, 31, 55-60.

Hashemi M, Sanaei S, Hashemi SM, Eskandari E, Bahari G (2018). Association of single nucleotide polymorphisms of the MDM4 gene with the susceptibility to breast cancer in a Southeast Iranian population sample. Clin Breast Cancer, 18, 883-91.

Hashemi M, Sarabandi S, Karami S, et al (2020). LMO1 polymorphisms and the risk of neuroblastoma: Assessment of meta-analysis of case-control studies. J Cell Mol Med, 24, 1160-8.

Hassanzarei S, Hashemi M, Sattarifard H, et al (2017). Genetic polymorphisms of HOTAIR gene are associated with the risk of breast cancer in a sample of southeast Iranian population. Tumor Biol, 39, 1010428317727539.

Hua Z, Li D, Xiang G, et al (2011). PD-1 polymorphisms are associated with sporadic breast cancer in Chinese Han population of Northeast China. Breast Cancer Res Tr, 129, 195-201.

Inman BA, Frigola X, Dong H, Kwon ED (2007). Costimulation, coinhibition and cancer. Curr Cancer Drug Tar, 7, 15-30.

Jayasekara H, MacInnis RJ, Hodge AM, et al (2016). Is breast cancer risk associated with alcohol intake before first fullterm pregnancy?. Cancer Cause Control, 27, 1167-74.

Juchem KW, Sacirbegovic F, Zhang C, et al (2018). PD-L1 prevents the development of autoimmune heart disease in graft-versus-host disease. J Immunol, 200, 834-46.

Karim R, Jordanova ES, Piersma SJ, et al (2009). Tumorexpressed $\mathrm{B} 7-\mathrm{H} 1$ and $\mathrm{B} 7-\mathrm{DC}$ in relation to $P D-1+\mathrm{T}-$ cell infiltration and survival of patients with cervical carcinoma. Clin Cancer Res, 15, 6341-7.

Keir ME, Butte MJ, Freeman GJ, Sharpe AH (2008). PD-1 and its ligands in tolerance and immunity. Annu Rev Immunol, 26, 677-704.

Kitts A, Sherry S (2002). The single nucleotide polymorphism database (dbSNP) of nucleotide sequence variation." The NCBI Handbook. McEntyre J, Ostell J, eds. Bethesda, MD: US National Center for Biotechnology Information.

Kuol N, Stojanovska L, Nurgali K, Apostolopoulos V (2018). $P D-1 / P D-L 1$ in disease. Immunotherapy-UK, 10, 149-60. 
Li L, Jia F, Bai P, et al (2016). Association between polymorphisms in long non-coding RNA PRNCR1 in 8q24 and risk of gastric cancer. Tumour Biol, 37, 299-303.

Li Q, Johnston N, Zheng X, et al (2016). miR-28 modulates exhaustive differentiation of $\mathrm{T}$ cells through silencing programmed cell death-1 and regulating cytokine secretion. Oncotarget, 7, 53735.

Ma Y, Liu X, Zhu J, et al (2015). Polymorphisms of co-inhibitory molecules (CTLA-4/PD-1/PD-L1) and the risk of non-small cell lung cancer in a Chinese population. Int J Clin Exp Med, 8, 16585-91.

McTiernan A, Friedenreich CM, Katzmarzyk PT, et al (2019). Physical activity in cancer prevention and survival: A Systematic Review. Med Sci Sport Exer, 51, 1252-61.

Namavar Jahromi F, Samadi M, Mojtahedi Z, et al (2017). "Association of $P D-1.5 \mathrm{C} / \mathrm{T}$, but Not $P D-1.3 \mathrm{G} / \mathrm{A}$, with Malignant and Benign Brain Tumors in Iranian Patients. Immunol Invest, 46, 469-80.

Nguyen LT, Ohashi PS (2015). Clinical blockade of PD1 and LAG3 - potential mechanisms of action. Nat Rev Immunol, 15, 45-56.

Ohigashi Y, Sho M, Yamada Y, et al (2005). Clinical significance of programmed death-1 ligand-1 and programmed death-1 ligand-2 expression in human esophageal cancer. Clin Cancer Res, 11, 2947-53.

Pizot C, Boniol M, Mullie P, et al (2016). Physical activity, hormone replacement therapy and breast cancer risk: A meta-analysis of prospective studies. Eur J Cancer, 52, 138-54.

Prokunina L, Castillejo-López C, Öberg F, et al (2002). A regulatory polymorphism in PDCD1 is associated with susceptibility to systemic lupus erythematosus in humans. Nat Genet, 32, 666-9.

Qiu H, Zheng L, Tang W, et al (2014). "Programmed death-1 $(P D-1)$ polymorphisms in Chinese patients with esophageal cancer. Clin Biochem, 47, 612-7.

Qiu H, Zheng L, Tang W, et al (2014). Programmed death-1 $(P D-1)$ polymorphisms in Chinese patients with esophageal cancer. Clin Biochem, 47.

Ramzi M, Arandi N, Saadi MI, et al (2018). Genetic variation of costimulatory molecules, including cytotoxic T-Lymphocyte antigen 4, inducible T-Cell costimulator, cluster differentiation 28, and programmed cell death 1 genes, in Iranian patients with leukemia. Exp Clin Transplant, 2017.

Ramzi M, Arandi N, Saadi MI, Yaghobi R, Geramizadeh B (2018). Genetic variation of costimulatory molecules, including cytotoxic T-Lymphocyte Antigen 4, inducible T-Cell costimulator, cluster differentiation 28 , and programmed cell death 1 genes, in Iranian patients with leukemia." Experimental and clinical transplantation: official journal of the Middle East Society for Organ Transplantation.

Ren H-T, Li Y-M, Wang X-J, et al (2016). PD-1 rs2227982 polymorphism is associated with the decreased risk of breast cancer in Northwest Chinese women: a hospital-based observational study. Medicine, 95.

Sacher AG, Gandhi L (2016). Biomarkers for the clinical use of $P D-1 / P D-L 1$ inhibitors in non-small-cell lung cancer: a review. JAMA Oncol, 2, 1217-22.

Salmaninejad A, Khoramshahi V, Azani A, et al (2018). PD-1 and cancer: molecular mechanisms and polymorphisms. Immunogenetics, 70, 73-86.

Savabkar S, Azimzadeh P, Chaleshi V, et al (2013). Programmed death-1 gene polymorphism $(P D-1.5 \mathrm{C} / \mathrm{T})$ is associated with gastric cancer. Gastroenterol Hepatol Bed Bench, 6, 178-82.

Schirmer MA, Lüske CM, Roppel S, et al (2016). Relevance of Sp binding site polymorphism in WWOX for treatment outcome in pancreatic cancer. J Natl Cancer Inst, 108.
Shiyanbola OO, Arao RF, Miglioretti DL, et al (2017). Emerging trends in family history of breast cancer and associated risk. Cancer Epidemiol Biomarkers Prev, 26, 1753-60.

Tan D, Sheng L, Yi Q-H (2018). Correlation of PD-1/PD-L1 polymorphisms and expressions with clinicopathologic features and prognosis of ovarian cancer. Cancer Biomark, 2, 287-97.

Tan D, Sheng L, Yi Q-H (2018). Correlation of PD-1/PD-L1 polymorphisms and expressions with clinicopathologic features and prognosis of ovarian cancer. Cancer Biomarkers Section A Dis Markers, 21, 287-97.

Tang W, Chen S, Chen Y, et al (2017). Programmed death-1 polymorphisms is associated with risk of esophagogastric junction adenocarcinoma in the Chinese han population: A case-control study involving 2,740 Subjects. Oncotarget, 8.

Taylor JG, Choi E-H, Foster CB, Chanock SJ (2001). Using genetic variation to study human disease. Trends $\mathrm{Mol} \mathrm{Med,}$ 7, 507-12.

Umami A, Sudalhar S, Pratama TWY, Fitri I, Firmansyah A (2020). Knowledge, barriers, and motivation related to breast and cervical cancer screening among women in Bojonegoro, East Java: A Qualitative Study. J Health Promotion Behav, 5, 1-10.

Vickers NJ (2017). Animal communication: When I'm calling you, will you answer too?. Curr Biol, 27, 713-5.

Wang W, Li F, Mao Y, et al (2013). A miR-570 binding site polymorphism in the B7-H1 gene is associated with the risk of gastric adenocarcinoma. Hum Genet, 132, 641-8.

Wu H, Zhang K, Gong P, et al (2014). A novel functional TagSNP Rs7560488 in the DNMT3A1 promoter is associated with susceptibility to gastric cancer by modulating promoter activity. PLoS One, 9.

Xie Q, Chen Z, Xia L, et al (2018). Correlations of PD-L1 gene polymorphisms with susceptibility and prognosis in hepatocellular carcinoma in a Chinese Han population. Gene, 674, 188-94.

Yamazaki T, Akiba H, Iwai H, et al (2002). Expression of programmed death 1 ligands by murine T cells and APC. J Immunol, 169, 5538-45.

Ye S, Dhillon S, Ke X, Collins AR, Day IN (2001). An efficient procedure for genotyping single nucleotide polymorphisms. Nucleic Acids Res, 29, e88.

Yousefi AR, Karimi MH, Shamsdin SA, et al (2013). PD-1 gene polymorphisms in Iranian patients with colorectal cancer. Lab Med, 44, 241-4.

Yu D (2019). The impact of exercise during radiation therapy for breast cancer patients.

Zhang J, Bu X, Wang H, et al (2018). Cyclin D-CDK4 kinase destabilizes $P D-L 1$ via cullin $3-$ SPOP to control cancer immune surveillance. Nature, 553, 91-5.

Zheng P, Zhou Z (2015). Human cancer immunotherapy with PD-1/PD-L1 blockade. Biomark Cancer, 7, BIC. S29325.

Zhou R-M, Li Y, Wang N, et al (2016). Association of programmed death-1 polymorphisms with the risk and prognosis of esophageal squamous cell carcinoma. Cancer Genet, 209, 365-75.

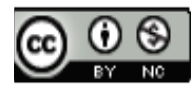

This work is licensed under a Creative Commons AttributionNon Commercial 4.0 International License. 